The Common Agricultural Policy of the European Union the present and the future

Non-EU Member States point of view 



\section{INSTITUTE OF AGRICULTURAL AND FOOD ECONOMICS NATIONAL RESEARCH INSTITUTE}

\section{The Common Agricultural Policy of the European Union - the present and the future}

\section{Non-EU Member States point of view}

Editors:

dr Marek Wigier

prof. dr hab. Andrzej Kowalski

Proceedings of the International Scientific Conference

"The Common Agricultural Policy of the European Union - the present and the future" Multi-Annual Programme 2015-2019

"The Polish and the EU agricultures 2020+. Challenges, chances, threats, proposals" 5-7 December 2017 Stare Jabłonki, Poland

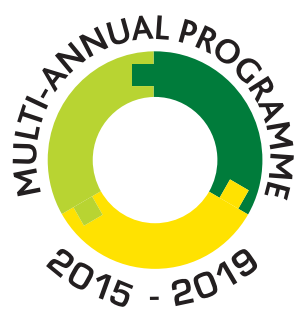

THE POLISH AND THE EU AGRICULTURES 2020+ CHALLENGES, CHANCES, THREATS, PROPOSALS

Warsaw 2018 
This monograph was prepared under the Multi-Annual Programme 2015-2019

"The Polish and the EU agricultures 2020+. Challenges, chances, threats, proposals".

The publication is a collection of selected papers delivered at the 22th edition of the International Scientific Conference organized by the Institute of Agricultural and Food Economics - National Research Institute. The theme of the conference was "The Common Agricultural Policy of the European Union the present and the future. The conference was placed on 5-7 December 2017 in Stary Jabłonki in Poland. Common Agricultural Policy was and still is one of the key pillars of European integration. Published in two volumes materials refer directly to the current and future of the CAP in EU and non EU member states, the strategic objectives and principles of agricultural policy for the agri-food sector and rural areas, address the issues of equilibrium between agriculture, forestry and land use, relate to the dilemmas for the EU budget and the CAP after 2020, CAP instruments and their adjustment, transformations of the rural economy and programming of the rural and agricultural policy, as well as productivity and production efficiency and tensions between sectoral action and between different models of territorial activities.

In the Scientific Committee of the Conference was participated: Prof. Andrzej Kowalski (IAFE-NRI, Poland), Prof. Drago Cvijanonivić (University of Kragujevac, Serbia), Prof. Thomas Doucha (IAEI, Czech Republic), Noureddin Driouech, PhD (CIHEAM, Italy), Prof. Szczepan Figiel (IAFE-NRI, Poland), Prof. Masahiko Gemma (Waseda University, Japan), Prof. Wojciech Józwiak (IAFE-NRI, Poland), Prof. Jacek Kulawik (IAFE-NRI, Poland), Prof. Yuriy Oleksiyovych Lupenko (IAE, Ukraina), Prof. Věra Majerová (CULS, Prague), Prof. Dimitre Nikolov (IAE, Bulgaria), Maire Nurmet, PhD (EMÜ, Estonia), Prof. Gabriel Popescu (ASE, Romania), Norbert Potori, PhD (AKI, Hungary), Prof. Włodzimierz Rembisz (IAFE-NRI, Poland), Piotr Szajner, PhD (IAFE-NRI, Poland), Prof. Alina Sikorska (IAFE-NRI, Poland), Prof. Jonel Subić (IAE, Serbia), Prof. Samuele Trestini (UNIPD, Italy), Prof. Olga Varchenko (Bila Tserkva National Agrarian University, Ukraine), Dipl.-Ing. Klaus Wagner (AWI, Austria), Marek Wigier, PhD (IAFE-NRI, Poland), Prof. Józef St. Zegar (IAFE-NRI, Poland)

In the Organising Committee of the Conference was participated: Małgorzata Bułkowska (IAFE-NRI, Poland), Anna Hankiewicz (IAFE-NRI, Poland), Joanna Jaroszewska (IAFE-NRI, Poland), Joanna Korczak (IAFE-NRI, Poland), Krzysztof Kossakowski (IAFE-NRI, Poland), Irena Mikiewicz (IAFE-NRI, Poland), Małgorzata Mikołajczyk (IAFE-NRI, Poland), Lech Parzuchowski (IAFE-NRI, Poland), Ewa Sierakowska (IAFE-NRI, Poland), Paulina Smakosz (IAFE-NRI, Poland), Leszek Ślipski (IAFE-NRI, Poland), Marek Wigier, PhD (IAFE-NRI, Poland).

Reviewers:

Professor Dimitre Nikolov, Institute of Agricultural Economics, Sofia, Bulgaria

Professor Gabriel Popescu, The Bucharest University of Economic Studies, Bucharest, Romania

Professor Samuele Trestini, University of Padva, Italy

Proofreader

Joanna Gozdera

Technical editors:

Joanna Jaroszewska, Barbara Pawtowska, Ewa Sierakowska, Kamila Tomaszewska,

Barbara Walkiewicz

Translated by

Summa Linguae S.A.

Cover Project

Leszek Ślipski

ISBN 978-83-7658-744-8

DOI: $10.30858 / \mathrm{pw} / 9788376587448$

Instytut Ekonomiki Rolnictwa i Gospodarki Żywnościowej

- Państwowy Instytut Badawczy

ul. Świętokrzyska 20, 00-002 Warszawa

tel.: (22) 5054444

faks: (22) 5054636

e-mail:dw@ierigz.waw.pl

http://www.ierigz.waw.pl 


\section{Contents}

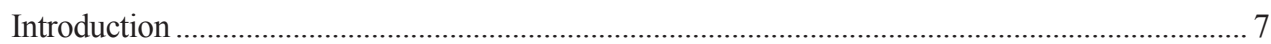

1 Urban agriculture: a framework for agricultural policy - present and future ......................... 15

Prof. Drago Cvijanović, Prof. Otilija Sedlak, Ph.D. Željko Vojinović

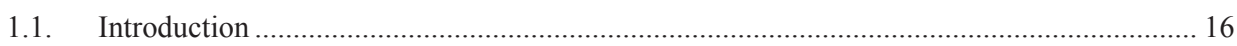

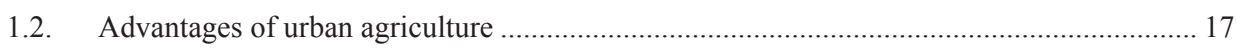

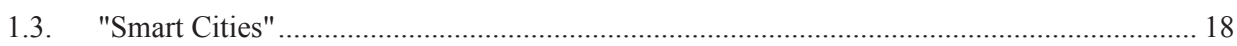

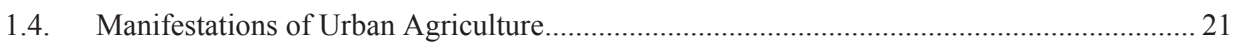

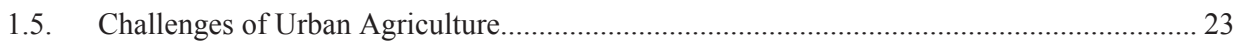

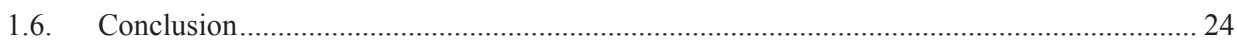

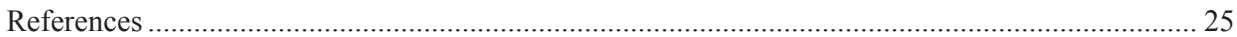

2 Land market and a village-keeping model of the agrarian system of Ukraine....................... 27

Dr Iurii Lupenko, Dr Valerii Zhuk

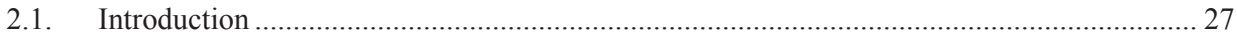

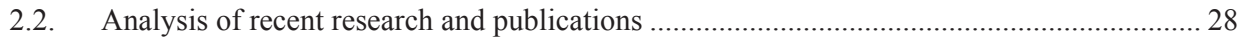

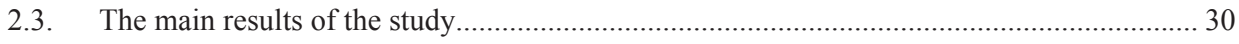

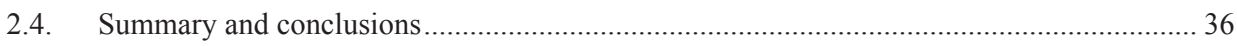

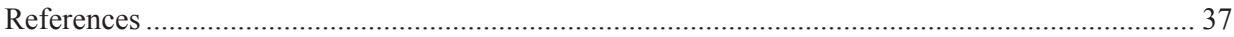

3 Agrarian policy in the European Union and financial support to Serbia................................ 38

PhD Biljana Grujić, PhD Predrag Vulović

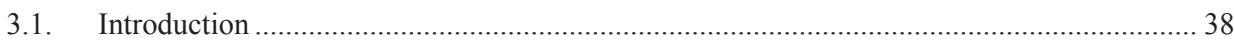

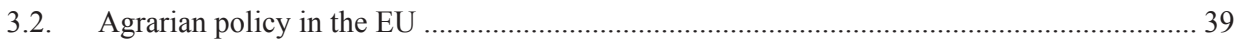

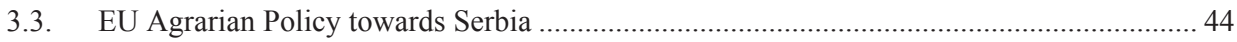

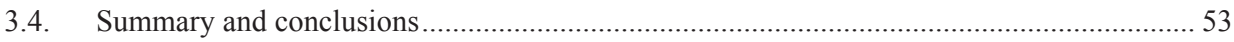

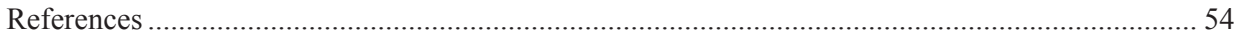

4 Ukrainian agricultural market regulation tools: their effectiveness and directions

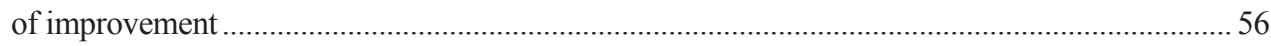

Prof. Olga Varchenko

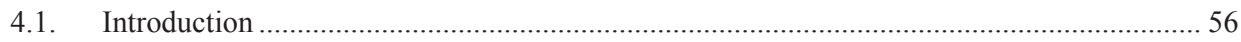

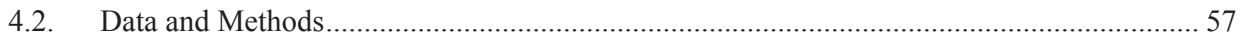

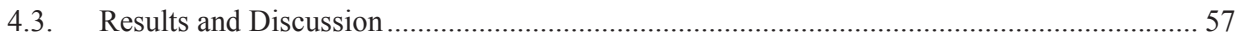

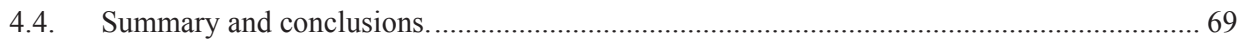

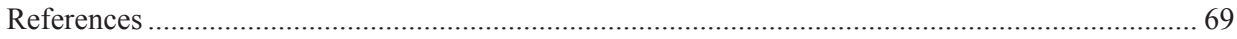


5 The Common Agricultural Policy of the European Union and the ways of its implementation in Ukraine

Dr Vasyl D. Zalizko, Prof. Nataliia M. Vdovenko, PhD Violeta L. Heraimovych, Assoc. Prof.

5.1. Introduction .71

5.2. The evolution of the EU Common agricultural policy .72

5.3. New priorities of the European Union for 2014-2020: strategic directions for Ukraine's agricultural sphere development

5.4. Organic component of the agricultural policy of Ukraine and common agricultural policy of the EU

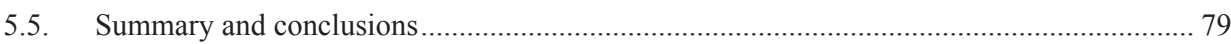

References 80

6 Farm's financing patterns and financial system development: evidence from Ukraine and Poland

Prof. Olena Oliynyk-Dunn, Prof. Viktor Adamenko

6.1. Introduction 81

6.2. Research methods 83

6.3. Results 84

6.4. Summary and conclusions 95

References .96

7 The moratorium on agricultural land sale as a limiting factor for rural development 97

Prof. Anatoliy Danylenko, PhD Tetyana Sokolska, PhD Olena Shust

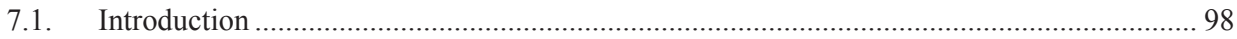

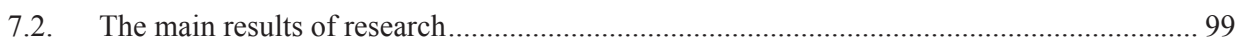

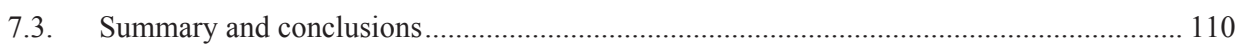

References

8 Solutions to the problems of rural territories development as a sign of their positive brand 114 Prof. Oleksandr Pavlov, Iryna Pavlova

8.1. Introduction 114

8.2. Problems of rural territories development 117

8.3. Branding as a marketing tool for solving the problems of rural territories development.... 124

8.4. Brand of rural territories development in Ukraine 127

8.5. Summary and conclusions 131

References 132

Instead of a summary 133

Annex I 


\title{
6 Farm's financing patterns and financial system development: evidence from Ukraine and Poland
}

\author{
Prof. Olena Oliynyk-Dunn, \\ National University of Life and Environmental Sciences of Ukraine, Faculty of \\ Economics, Department of Banking \\ Prof. Viktor Adamenko, \\ Kyiv National University of Trade and Economics, Faculty of Economics, \\ Management and Psychology, Department of Economics and Business Finance
}

DOI: $10.30858 / \mathrm{pw} / 9788376587448.6$

\begin{abstract}
Using integral indicator of financial system development, we investigate how the financial system in Ukraine and Poland developed during 2010-2015 and how financial system development affects financing of farms in Ukraine and Poland. The results of the study indicate that there was a rapid decline in the development of Ukraine's financial system during 2010-2015 and positive tendency in the development of Polish financial system. The results of the paper deny the findings of some researchers that in countries with a less developed financial system, the role of external financing is lower. The results of the study showed that the dependence of Ukrainian farms on external financing increased significantly during 2010-2015. The main feature was that external financing grew not due to an increase in bank loans but due to informal sources. Contrary to Ukraine in Poland, the study revealed a strong statistical relationship between the integral indicators of the financial system and indicators characterizing the financing patterns of agricultural enterprises. This gives some arguments in favour of the confirmation of the hypothesis that the stable development of the financial system in advanced economies, generates a gradual increase the role of long-term debt and perpetuates its own sources of financing of agricultural enterprises.
\end{abstract}

Keywords: financial system, financial patterns, integral indicator of financial system development, farms, Ukraine, Poland

JEL Codes: G10; G21; G32

\subsection{Introduction}

Recent scientific papers studying the financing patterns around the world emphasize the importance of financial system differences on capital structure (Hackethal et al., 2004; Booth et al., 2001; Demirguc-Kunt and Maksimovic, 1996, 1999; Beck et al., 2008; Giannetti, 2003; De Jong et al., 2008; Fan et al., 2010). 
Hackethal et al. (2004) show that the differences between the financing patterns used in three selected countries (U.S.A., Germany, and Japan) are largely consistent with the differences between financial sector structures, corporate governance regimes and several other financial system elements of these countries.

Demirgüç-Kunt and Maksimovic (1999) find systematic differences in the use of long-term debt between developed and developing countries, and small and large firms. In developed countries with good legal systems, and consequently good financial systems, firms have more long term debt, which represents a greater proportion of their total debt. Also, they find that large firms have more long-term debt as a proportion of total assets and debt compared to smaller firms.

Beck et al. (2008) find that firm size, financial development and property rights protection are important factors in explaining the observed variation in financing patterns. Firms in countries with poor financial institutions and small firms use less external finance, especially bank finance.

De Jong et al. (2008) state that in countries with a better legal environment, and more stable and healthier economic conditions, firms are not only likely to take on more debt, and the effects of firm-level determinants of financial leverage are also reinforced.

Giannetti (2003) analyses a large sample of unlisted firms from eight European countries and finds a significant positive influence of a few institutional variables such as creditor protection, stock market development and legal enforcement on the financial leverage of individual firms.

Fan et al. (2010) find contrary results compared with the studies mentioned above. They contend that "firms in countries that are viewed as more corrupt tend to use less equity and more debt, especially short-term debt, while firms operating within legal systems that provide better protection for financial claimants tend to have capital structures with more equity, and relatively more long-term debt".

In this paper, we investigate whether the financing patterns of farms in Ukraine and Poland depend on the level of financial system development that has been the focus of the prior literature. A direct implication of previous studies is that in countries with weak financial systems, farms obtain less external financing and that this results in lower growth. We also explore the relation between farms' external financing and a country's financial institutions and consider a broader spectrum of external financing sources such as supplier credit and informal sources. 


\subsection{Research methods}

The most common (traditional) approach to assessing the impact of one research object (phenomenon or process) on the development of another object is based on an analysis of the interdependence of the indicators characterizing both of these objects. This interdependence could be analyzed using different methodological approaches; the most common are the following:

1) Time series analysis;

2) Regression analysis.

These two methodological approaches were chosen to assess the impact of financial system development and financing patterns of farms in Ukraine and Poland from 2010 to 2015.

To investigate the level of financial system development we used the model «3+3», which allows simplicity and affordability, and provides an adequate comparative analysis of financial systems of individual countries and identifies their type (bank-based or market-based) ${ }^{9}$.

The integral indicator of level development is calculated as an area of the geometric figure (hexagon - for financial system, triangle is for banking sector and financial markets), with the tops in a coordinate system of 6 or 3 axes. Each axis corresponds to one of the indicators listed in the Table 1. On each of the six or three axes, we plot the relative values, which are defined as a share of the maximum (or reference) value of the indicator.

Table 1. The indicators of the simplified model of the integral indicator

\begin{tabular}{|c|c|c|c|}
\hline \multirow[b]{2}{*}{ Integral indicator } & \multicolumn{3}{|c|}{ Components of the integral indicator } \\
\hline & $\begin{array}{l}\text { Scale (extensity } \\
\text { development) }\end{array}$ & The resources & The efficiency \\
\hline $\begin{array}{l}\text { Financial } \\
\text { development: } \\
\text { Banking sector }\end{array}$ & $\begin{array}{lr}\text { Commercial } & \text { bank } \\
\text { branches(per } & 100,000 \\
\text { adults) } & \end{array}$ & $\begin{array}{l}\text { Bank deposits to } \\
\text { GDP (\%) }\end{array}$ & $\begin{array}{l}\text { Domestic credit to } \\
\text { private sector by } \\
\text { banks }(\% \text { of GDP) }\end{array}$ \\
\hline Financial markets & $\begin{array}{l}\text { Listed domestic } \\
\text { companies (per } 1,000 \\
\text { enterprises) }\end{array}$ & $\begin{array}{l}\text { Stock market } \\
\text { capitalization to } \\
\text { GDP }(\%)\end{array}$ & $\begin{array}{l}\text { Stocks traded, total } \\
\text { value }(\% \text { of GDP) }\end{array}$ \\
\hline
\end{tabular}

Source: own development based on data (World Bank 2017a, 2017b).

\footnotetext{
9 A more detailed explanation of the model " $3+3$ " is in Oliynyk et al. (2015) and Oliynyk-Dunn (2017).
} 
The integral indicator of the financial system development level as an area of the hexagon can be calculated by the formula:

$$
I I_{F S}=\frac{1}{2} \times\left[\left(I_{1} \times I_{2}\right)+\left(I_{2} \times I_{3}\right)+\cdots+\left(I_{6} \times I_{1}\right) \times \sin 60^{\circ}\right] \text {, }
$$

where IIFS - the integral indicator of the financial development level;

I1, I2, ...I6 - relative values of indicators used in the model " $3+3 "$ (6 indicators): I1, I2, I3 - relative values of banking sector indicators, I4, I5, I6 relative values of the financial market indicators (see table 1).

The integral indicator of the banking sector or financial markets level as an area of the triangle can be calculated by the formula:

$$
I I_{B S / F M}=\frac{1}{2} \times\left[\left(I_{1} \times I_{2}\right)+\left(I_{2} \times I_{3}\right)+\left(I_{3} \times I_{1}\right) \times \sin 120^{\circ}\right] \text {, }
$$

where IIBS/FM - the integral indicator of the banking sector or financial markets level;

I1, I2, I3 - relative values of indicators of scale, resources and efficiency.

The integral indicator describes the relative development level and it cannot be calculated only for one country for one year without comparison with another country or establishing reference values or time-series data.

We used the coefficient of financial leverage, ratio working capital to current assets, ratio accounts payable to current assets, the share of current liabilities in the total amount of liabilities, the share of bank loans in the total amount of liabilities, the share of short-term bank loans in current liabilities to analyse the financing patterns of agricultural enterprises in Ukraine and Poland.

\subsection{Results}

The financial system of Ukraine during the last decade was experiencing a rather difficult period. During 2010- 013, the value of the integral indicator of the level of financial system development of Ukraine indicates a post-crisis stagnation (see Figure 1). The rapid decline in the level of development of Ukraine's financial system was observed in 2015 after a slight recovery in 2014.

The level of development of Poland's financial system showed a general upward trend (the last of 2015 is the only exception when this level has slightly decreased). 
Figure 1. Dynamics of financial system development of Ukraine and Poland according to the model " $3+3$ ", $2010-2015$

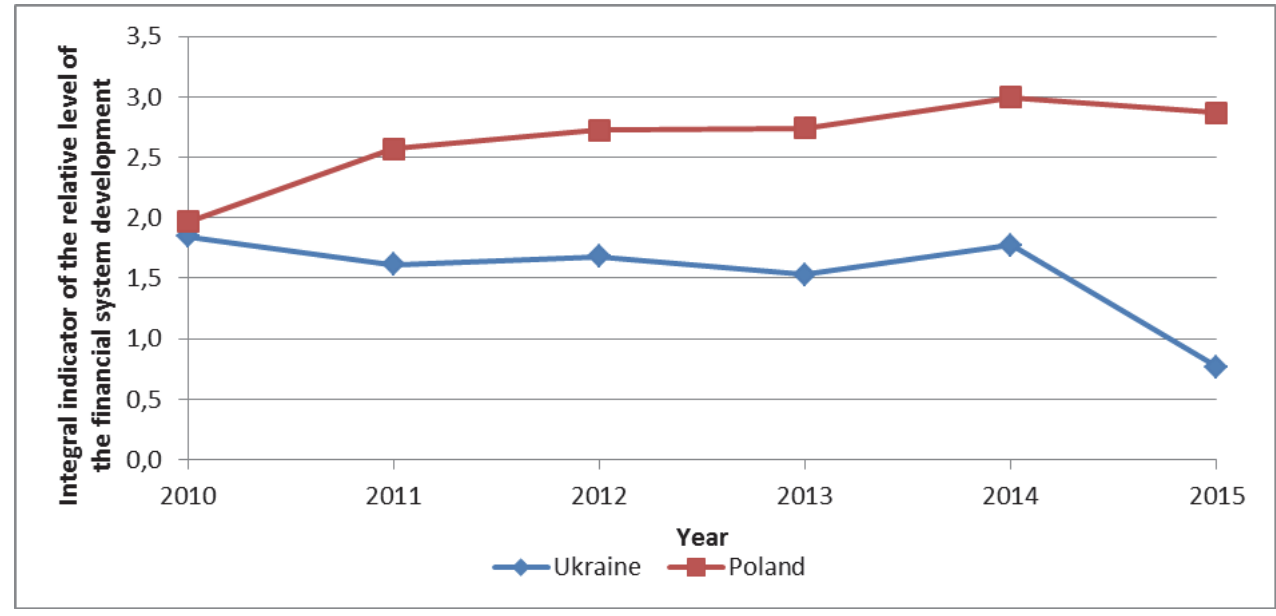

Source: Own elaboration based on data (World Bank 2017a, 2017b).

Figure 2 illustrates significant transformational changes in the financial system of Ukraine. The main reasons for negative changes in 2015 were: 1) the massive bankruptcy of Ukrainian commercial banks; 2) rapid depreciation of securities of Ukrainian issuers on the domestic stock market. The first reason, caused a significant decrease in the number of bank branches in the country (see indicator Commercial Bank branches per 100,000 adults in Figure 2), and the second reason brought the collapse of the indicator of the stock market capitalization to GDP to an unacceptably low value.

The financial system of Poland demonstrated positive tendency in 2015 compare with 2010. Particularly the most significant growth was demonstrated by the stock market (especially its scale indicator).

According to the data of Figure 3 the financial system of Poland demonstrated a significant development advantage over Ukraine in 2010 and 2015 with the exception of the efficiency of the functioning of the banking component. In spite of a catastrophic reduction in the scale of the banking component of the financial system of Ukraine (as a result of the bankruptcy many banks), this component provides a higher level of private sector lending to GDP. One of the reasons for this phenomenon is the degradation of the Ukrainian stock market as a component of the financial system, resulting in an additional burden on the banking component regarding the redistribution of financial resources in the economy. 
Figure 2. Relative level of financial system development of Ukraine and Poland in 2010 and 2015 by the model " $3+3$ "

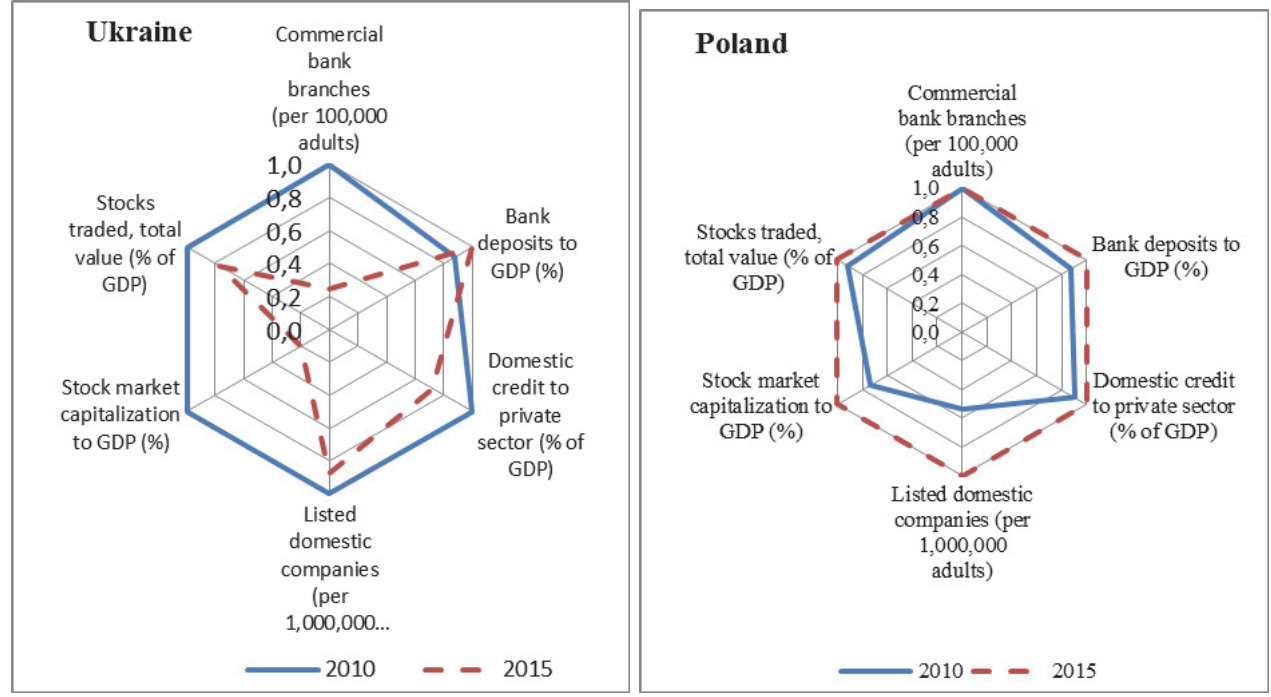

Source: Own elaboration based on data (World Bank 2017a, 2017b).

Figure 3. Relationship between the level of financial system development of Ukraine and Poland in 2010 and 2015

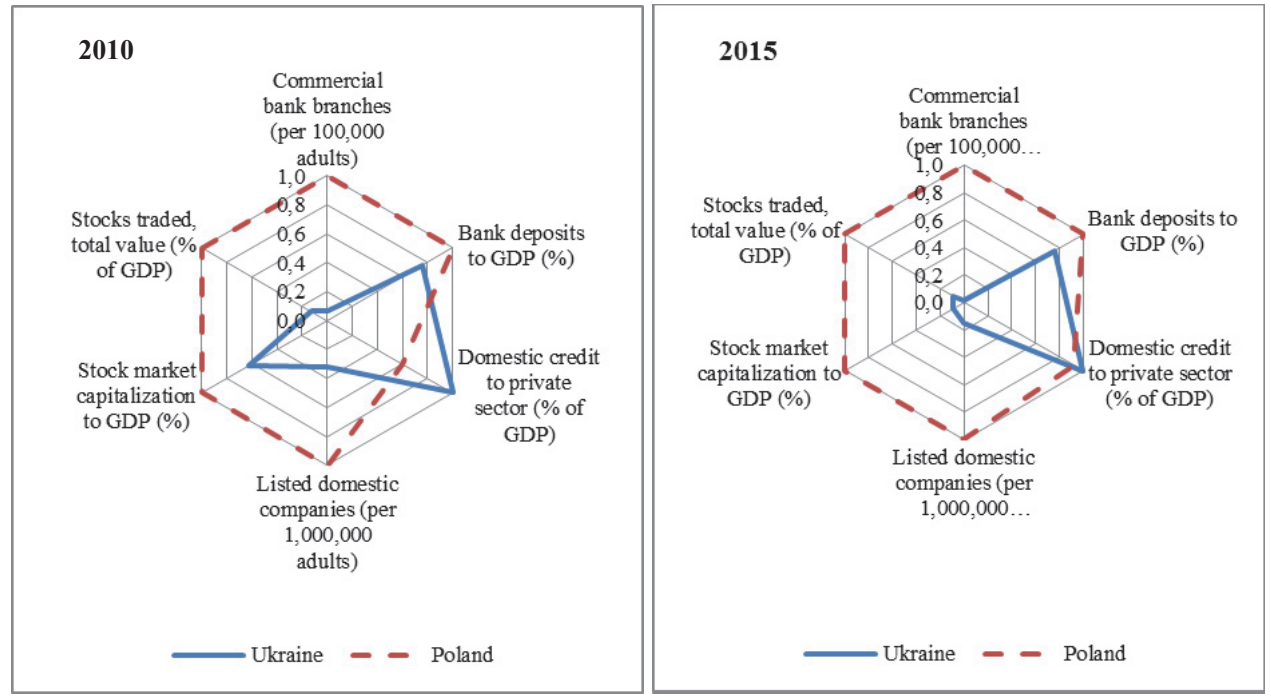

Source: Own elaboration based on data (World Bank 2017a, 2017b). 
In Ukraine general negative changes are also observed in the development of each of the two components of the financial system: banking and market. According to the data of Figure 4, despite differences in dynamics at the initial stage of the study period, in 2015 both components showed a decline in development.

It is obvious that this kind of development of the Ukraine's financial system and its components was associated with the general socio-political and economic situation in the country, in particular with the military conflict in the Donbass, which began in 2014, the loss of Russian markets and the depreciation of the national currency. The dynamics of both components of Poland's financial system is characteristic of countries that successfully developed.

Figure 4. Dynamics of development of banking and market components of financial system of Ukraine and Poland according to the model " $3+3$ ",

2010-2015
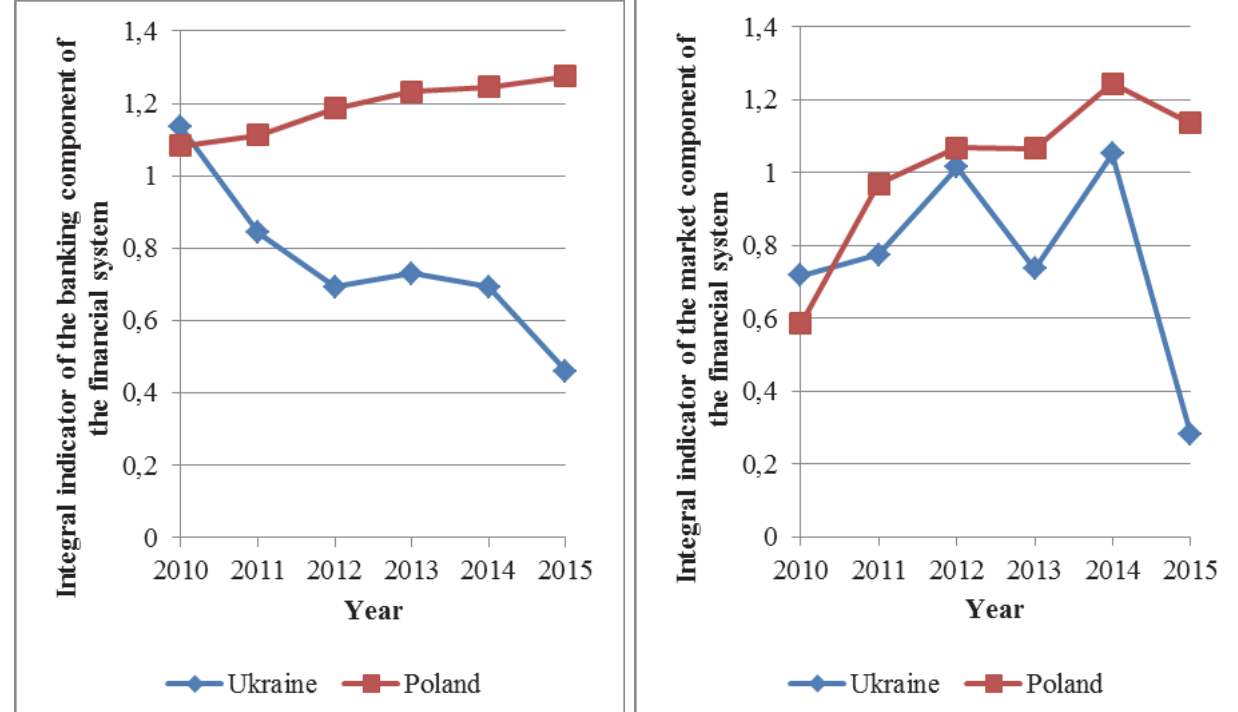

Source: Own elaboration based on data (World Bank 2017a, 2017b).

We observe that in Ukraine the coefficient of variation of the financial system development indicator are more volatile than in Poland (see Table 2). The fact that in Ukraine, the financial system development indicator is less than for certain components of financial system is explained covariance (the effect of the portfolio - fluctuations of individual components are partly offset by each other).

The coefficient of variation of the financial system development indicator illustrates the stability of the development of the Polish financial system, especially 
the banking component; somewhat more volatile was the development of a market component, but it is quite natural in view of the mechanism of market pricing.

Table 2. Volatility of the financial system of Ukraine and Poland for 2010-2015, \%

\begin{tabular}{|l|c|c|}
\hline \multicolumn{1}{|c|}{$\begin{array}{c}\text { Coefficient of variation of } \\
\text { the integral indicator }\end{array}$} & Ukraine & Poland \\
\hline Financial system & 23,3 & 12,5 \\
\hline $\begin{array}{l}\text { Bank Component of Financial } \\
\text { System }\end{array}$ & 26,7 & 5,9 \\
\hline $\begin{array}{l}\text { Market Component of } \\
\text { Financial System }\end{array}$ & 33,1 & 20,6 \\
\hline
\end{tabular}

Source: Own elaboration based on data (World Bank 2017a, 2017b).

During the research period, significant changes were also observed in the indicators characterizing the financing patterns of Ukrainian farms. According to the data of the Table 3 and Figure 5, all of these indicators had generally unfavourable dynamics and worsened in 2015 compared with 2010. Particularly negative for Ukrainian agricultural enterprises were changes in the two indicators (indicated in Table 3): the financial leverage and the ratio of working capital to current assets.

In Poland we observed opposite situation. The financial leverage decreased slightly in 2015 compared to 2010. As well, Poland's farms has increased the sufficiency of working capital in contrast to Ukraine. An increase in the share of long-term financing is also positive.

Table 3. Indicators, which characterize the financing patterns of agricultural enterprises in Ukraine and Poland, 2010 - 2015

\begin{tabular}{|l|c|c|c|c|}
\hline \multirow{2}{*}{ Indicator } & \multicolumn{2}{|c|}{ Ukraine } & \multicolumn{2}{c|}{ Poland } \\
\cline { 2 - 5 } & 2010 & 2015 & 2010 & 2015 \\
\hline Financial leverage & 0,926 & 1,453 & 0,389 & 0,373 \\
\hline Ratio working capital to current assets & 0,436 & 0,356 & 0,608 & 0,695 \\
\hline $\begin{array}{l}\text { Ratio accounts payable to current } \\
\text { assets }\end{array}$ & 0,452 & 0,266 & 0,266 & 0,191 \\
\hline $\begin{array}{l}\text { The share of current liabilities in the } \\
\text { total amount of liabilities }\end{array}$ & 67,5 & 79,7 & 55,6 & 48,5 \\
\hline $\begin{array}{l}\text { The share of bank loans in the total } \\
\text { amount of liabilities }\end{array}$ & 16,4 & 10,8 & 17,9 & 22,1 \\
\hline $\begin{array}{l}\text { Share of short-term bank loans in } \\
\text { current liabilities }\end{array}$ & 3,4 & 48,0 & 14,3 & 15,3 \\
\hline
\end{tabular}

Source: Own elaboration based on data (SSSU 2017, CSOP 2017). 
Figure 5. Dynamics of a) financial leverage and b) the share of working assets financed by working capital of agricultural enterprises in Ukraine and Poland for 2010-2015
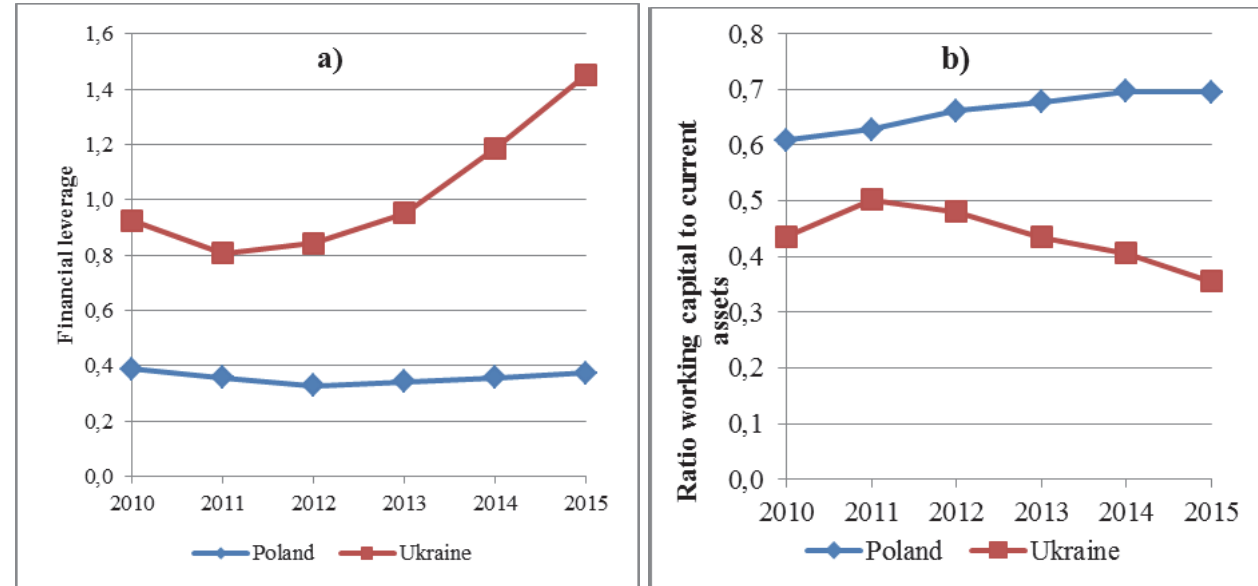

Source: Own elaboration based on data (SSSU 2017, CSOP 2017).

In spite of the general negative character of changes in the integral indicators of the financial system development and indicators characterizing the financing patterns of agricultural enterprises in Ukraine, in the process of correlation analysis a strong statistical relationship between them could not be found (with some exceptions), as evidenced by Table 4.

In Poland (as opposed to Ukraine) there is a significant statistical relationship between the main indicators characterizing the financing patterns of agricultural enterprises and the integral indicators of the development of the financial system. An exception is the financial leverage, which is significantly dependent on factors affecting the formation of enterprise's internal financial resources (free cash flows related to net income and depreciation). Also, the weak link is the last indicator, due to the fact that by nature it is not related to the activities of financial institutions and markets.

The relationship between the certain indicators characterizing the financing patterns of agricultural enterprises and the integral indicators of the development of the financial system of Poland proved to be so significant that it allowed to construct statistically reliable regression models, despite the small number of values in the dynamic series (Figure 6). This suggest that the development of the farm's financing patterns and the development of the financial system in Poland are directly linked. 
Table 4. Correlation coefficients between the integral indicators of the development level of the financial system and the indicators characterizing the development of financing patterns of agricultural enterprises in Ukraine and Poland, 2010-2015

\begin{tabular}{|l|c|c|c|c|c|c|}
\hline \multirow{2}{*}{ Indicator } & \multicolumn{3}{|c|}{ Ukraine } & \multicolumn{3}{c|}{ Poland } \\
\cline { 2 - 7 } & $\begin{array}{c}\text { Financial } \\
\text { System }\end{array}$ & $\begin{array}{c}\text { Banking } \\
\text { Sector }\end{array}$ & $\begin{array}{c}\text { Financial } \\
\text { Markets }\end{array}$ & $\begin{array}{c}\text { Financial } \\
\text { System }\end{array}$ & $\begin{array}{c}\text { Banking } \\
\text { Sector }\end{array}$ & $\begin{array}{c}\text { Financial } \\
\text { Markets }\end{array}$ \\
\hline Financial leverage & $-0,752$ & $-0,656$ & $-0,592$ & $-0,568$ & $-0,314$ & $-0,585$ \\
\hline $\begin{array}{l}\text { Ratio working capital to } \\
\text { current assets }\end{array}$ & 0,644 & 0,491 & 0,581 & 0,914 & 0,989 & 0,903 \\
\hline $\begin{array}{l}\text { Ratio accounts payable to } \\
\text { current assets }\end{array}$ & 0,538 & 0,719 & 0,223 & $-0,947$ & $-0,973$ & $-0,939$ \\
\hline $\begin{array}{l}\text { The share of current } \\
\text { liabilities in the total } \\
\text { amount of liabilities }\end{array}$ & $-0,854$ & $-0,849$ & $-0,587$ & $-0,855$ & $-0,969$ & $-0,843$ \\
\hline $\begin{array}{l}\text { The share of bank loans } \\
\text { in the total amount of } \\
\text { liabilities }\end{array}$ & 0,871 & 0,480 & 0,840 & 0,806 & 0,923 & 0,793 \\
\hline $\begin{array}{l}\text { Share of short-term bank } \\
\text { loans in current liabilities }\end{array}$ & $-0,653$ & $-0,691$ & $-0,415$ & 0,563 & 0,299 & 0,580 \\
\hline
\end{tabular}

Source: Own elaboration based on data (World Bank 2017a, 2017b, SSSU 2017, CSOP 2017).

Figure 6. Regression models that illustrate the statistical dependence between the integral indicator of the banking component of the financial system and the key indicators of financing of agricultural enterprises in Poland for 2010-2015 ${ }^{10}$
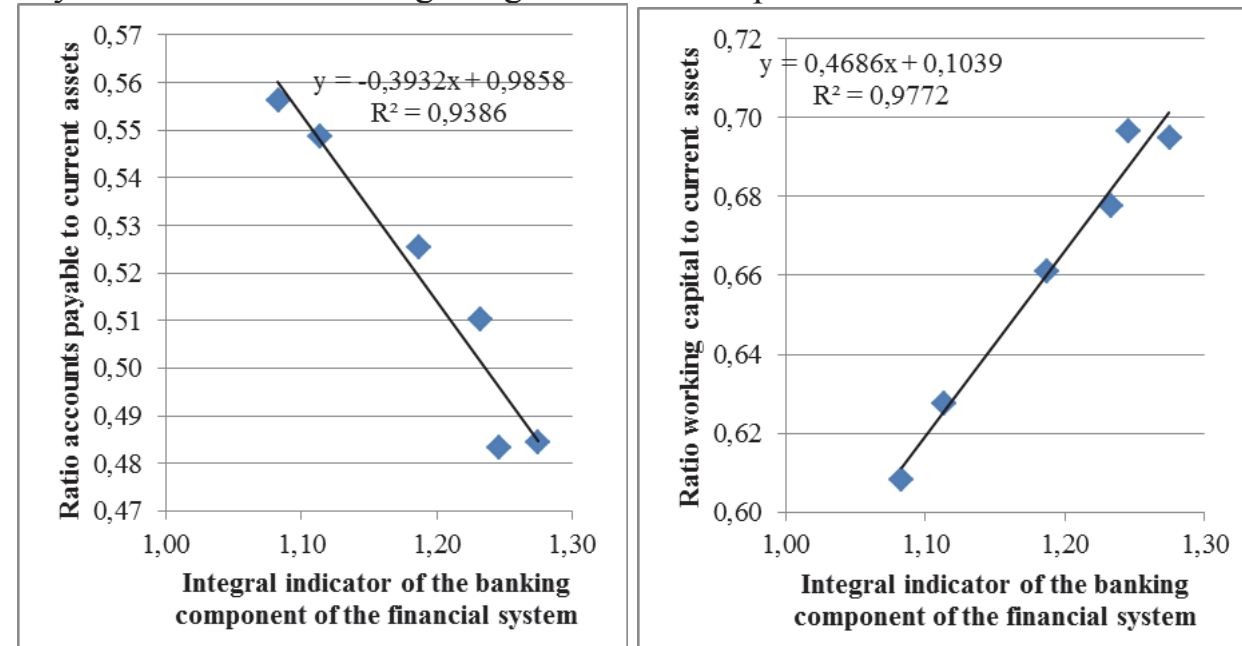

Source: Own elaboration based on data (World Bank 2017a, 2017b, CSOP 2017).

${ }^{10}$ All regression coefficients in the model are statistically significant (p-value does not exceed 0.05 ); adequacy model confirms the absence of autocorrelation residues, homoscedasticity condition is not violated. 
To identify the most significant factors of influence on farm's financing patterns, a correlation analysis was carried out, the results of which are illustrated in Table 5. In Ukraine (as opposed to Poland), the development of financing patterns of agricultural enterprises is more related to the depreciation of the national currency and the general political situation in the country, as evidenced by the results of the correlation analysis (see Table 5).

The most significant factor in Ukraine was the statistical relationship between the coefficient of the financial leverage of agricultural enterprises and the average rate of national currency to the US\$, which is described by the pairwise linear regression equation (Figure 7).

Table 5. Coefficients of the pair correlation between indicators which characterize the financing patterns of agricultural enterprises and the indicators considered by the potential factors of influence on this financing patterns in Ukraine and Poland, 2010-2015

\begin{tabular}{|c|c|c|c|c|c|}
\hline Indicator & $\begin{array}{c}\text { Political } \\
\text { Stability and } \\
\text { Absence of } \\
\text { Violence/ } \\
\text { Terrorism } \\
\text { Index }\end{array}$ & $\begin{array}{l}\text { The Global } \\
\text { Competitive- } \\
\text { ness Index }\end{array}$ & $\begin{array}{l}\text { GDP per } \\
\text { capita } \\
\text { (current } \\
\text { US\$) }\end{array}$ & $\begin{array}{l}\text { Agricultural } \\
\text { products (in } \\
\text { comparative } \\
\text { prices }\end{array}$ & $\begin{array}{l}\text { The average } \\
\text { rate of } \\
\text { national } \\
\text { currency to } \\
\text { the US\$ }\end{array}$ \\
\hline $\begin{array}{l}\text { Financial } \\
\text { leverage }\end{array}$ & $\frac{-0,905}{-0,228}$ & $\frac{0,139}{0,904}$ & $\frac{-0,827}{-0,487}$ & $\frac{0,443}{-0,816}$ & $\frac{0,951}{0,073}$ \\
\hline $\begin{array}{l}\text { Ratio working } \\
\text { capital to } \\
\text { current assets }\end{array}$ & $\frac{0,842}{-0,797}$ & $\frac{-0,018}{-0,242}$ & $\frac{0,775}{0,281}$ & $\frac{-0,412}{0,714}$ & $\frac{-0,846}{0,661}$ \\
\hline $\begin{array}{l}\text { Ratio accounts } \\
\text { payable to } \\
\text { current assets }\end{array}$ & $\frac{0,931}{0,725}$ & $\frac{-0,454}{0,354}$ & $\frac{0,650}{-0,344}$ & $\frac{-0,533}{-0,787}$ & $\frac{-0,805}{-0,609}$ \\
\hline $\begin{array}{l}\text { The share of } \\
\text { current liabilities } \\
\text { in the total } \\
\text { amount of } \\
\text { liabilities }\end{array}$ & $\frac{-0,804}{0,895}$ & $\frac{0,329}{0,066}$ & $\frac{-0,566}{-0,221}$ & $\frac{0,569}{-0,586}$ & $\frac{0,889}{-0,690}$ \\
\hline $\begin{array}{l}\text { The share of } \\
\text { bank loans in the } \\
\text { total amount of } \\
\text { liabilities }\end{array}$ & $\frac{0,400}{-0,922}$ & $\frac{0,224}{0,057}$ & $\frac{0,851}{0,134}$ & $\frac{0,103}{0,465}$ & $\frac{-0,880}{0,736}$ \\
\hline $\begin{array}{l}\text { Share of short- } \\
\text { term bank loans } \\
\text { in current } \\
\text { liabilities }\end{array}$ & $\frac{-0,951}{0,220}$ & $\frac{0,295}{-0,931}$ & $\frac{-0,779}{0,588}$ & $\frac{0,487}{0,851}$ & $\frac{0,907}{-0,160}$ \\
\hline
\end{tabular}

Ukraine - in the numerator, Poland - in the denominator

Source: Own elaboration based on data (World Bank 2017a, 2017b, 2017c, SSSU 2017, NBU 2017, CSOP 2017). 
Figure 7. Regression model for the financial leverage of agricultural enterprises of Ukraine, based on data for 2010-2015 ${ }^{11}$

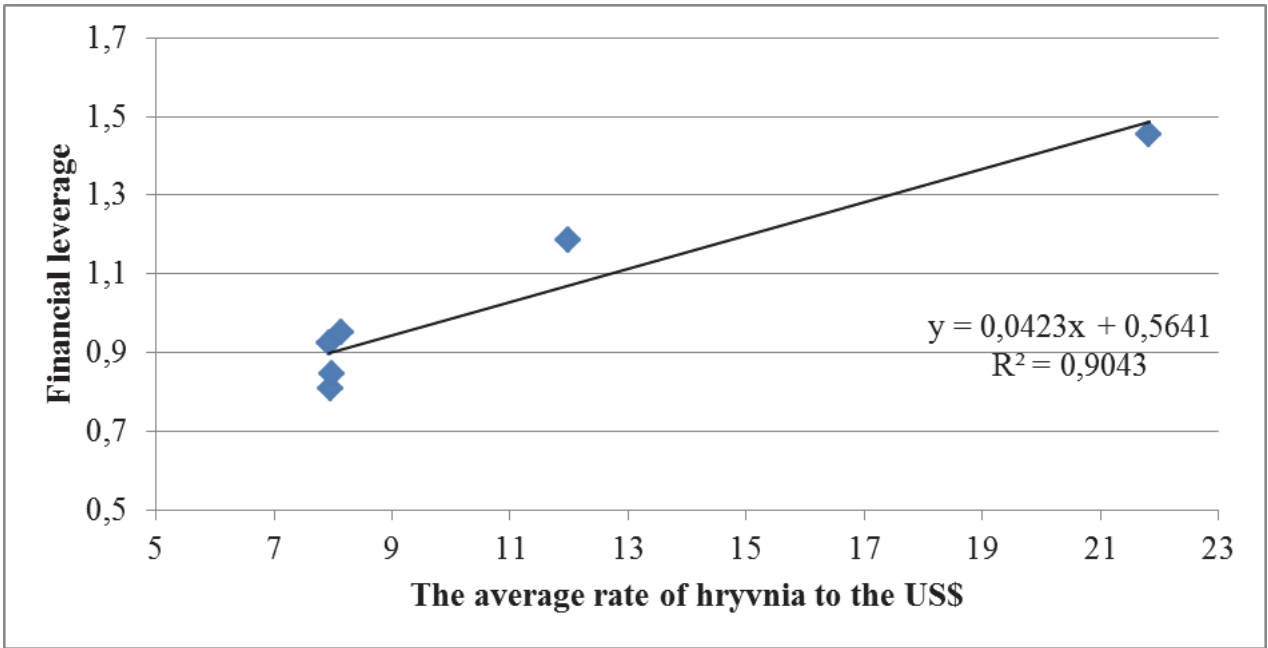

Source: Own elaboration based on data (NBU 2017, SSSU 2017).

The results of calculations of the pair correlation coefficients (see Table 4) indicate the average degree of influence of the financial system on the financing patterns of Ukrainian agricultural enterprises. These results can be considered quite logical in view of the specific changes that have occurred in the sources of funding in recent years of the study period. The main feature is the significant growth of other current liabilities, the amount at the end of 2015, according to the State Statistics Committee of Ukraine, exceeded accounts payable and amounted to almost 120 billion UAH, or almost half of the total volume of current liabilities of enterprises. Figure 8 illustrates the dynamics of individual components of current liabilities of Ukrainian and Polish agricultural enterprises. As far as Poland is concerned, there is stability in the share of other current liabilities.

\footnotetext{
${ }^{11}$ All regression coefficients in the model are statistically significant (p-value does not exceed 0.05 ); adequacy model confirms the absence of autocorrelation residues, homoscedasticity condition is not violated.
} 
Figure 8. Dynamics of the share "Other current liabilities" in the total annual average volume of current liabilities of agricultural enterprises in Ukraine and Poland for 2010-2015

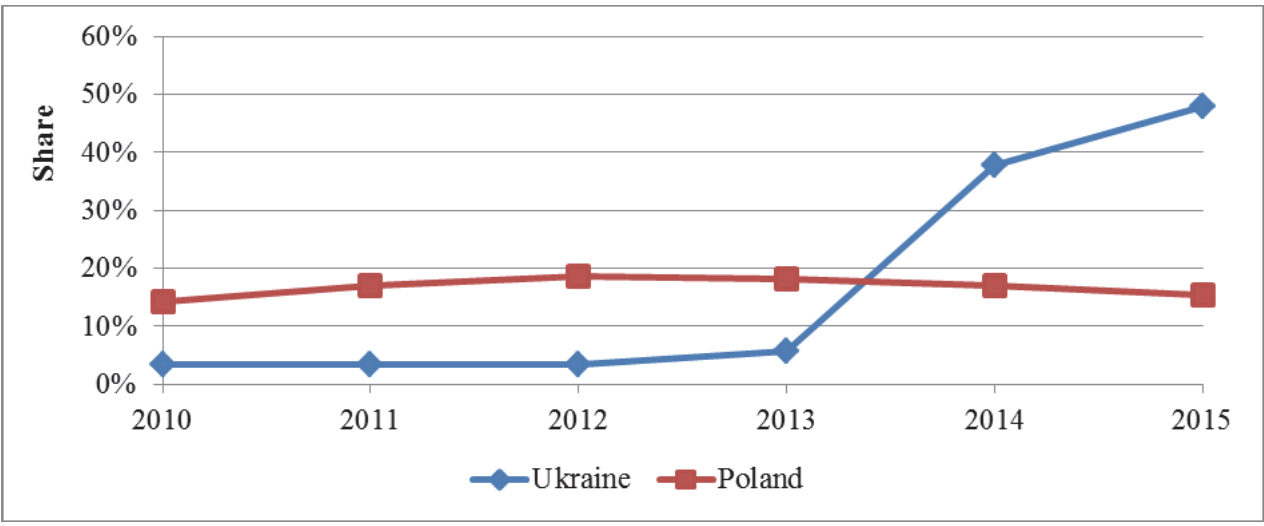

Source: Own elaboration based on data (SSSU 2017, CSOP 2017).

According to official statistics of Ukraine, other current liabilities of enterprises are reflected: current provisions, future income and deferred commission income from reinsurers, as well as an unidentified component of "other". This unidentified component is more than $95 \%$ of the total volume of other current liabilities, the dynamics of which is illustrated in Figure 9. This process partially became possible due to changes in the Tax Code of Ukraine, which allowed businesses to provide each other with interest-free financial assistance without the use of traditional financial instruments.

Figure 9. Dynamics of the share "Other current liabilities" in the total annual average volume of current liabilities of agricultural enterprises in Ukraine and

Poland for 2010-2015

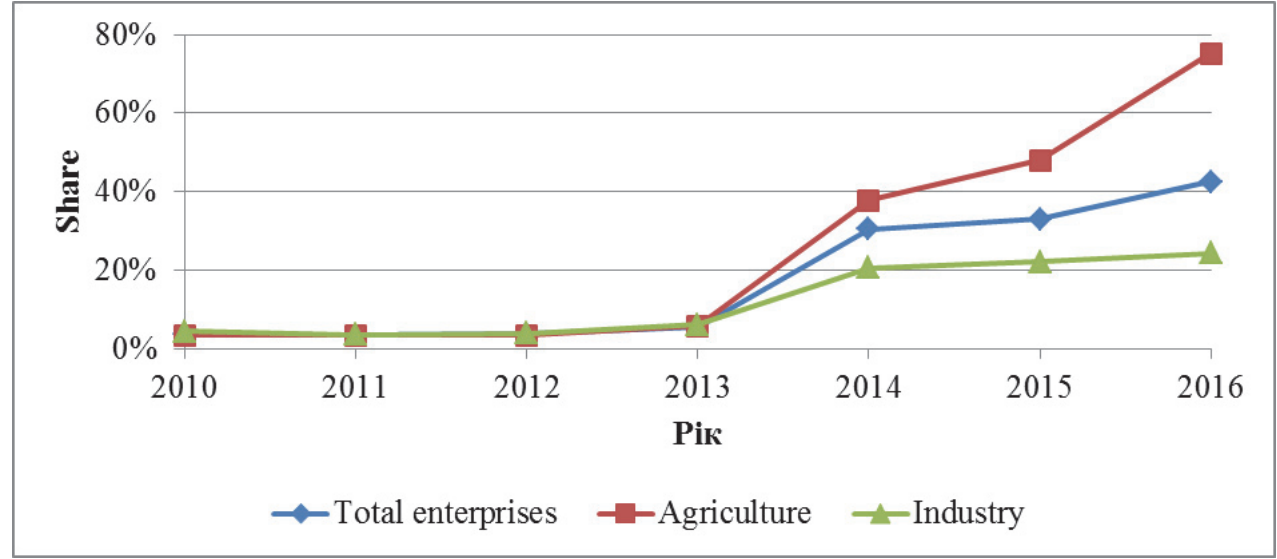

Source: Own elaboration based on data (SSSU 2017). 
We also found a significant statistical relationship between the average rate of hryvnia to the US $\$$ and the share of other current liabilities in total current liabilities for agricultural enterprises in Ukraine in the years 2010-2016 (Figure 10). This gives grounds for concluding that the instability of the hryvnia leads to the refusal to use the services of the financial system with the availability of financial instruments that arise outside the financial institutions.

Figure 10. A simple linear regression model between the average rate of hryvnia to the US\$ and the share of other current liabilities in the total current liabilities for agricultural enterprises in Ukraine, 2010-2016 ${ }^{12}$

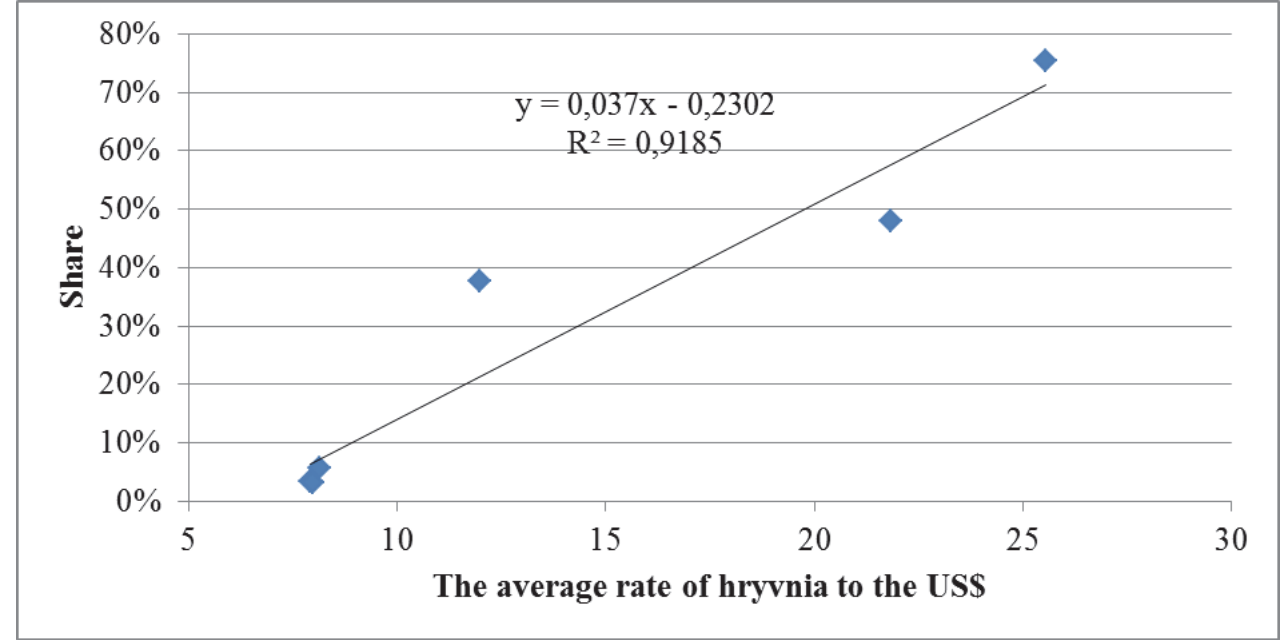

Source: Own elaboration based on data (SSSU 2017, NBU 2017).

As a result, the impact of the financial system's development on changes in financing patterns of Ukrainian agricultural enterprises has become somewhat weaker, compared with the situation before 2014. Consequently, it can be argued that the growth of other current liabilities of enterprises has become an additional significant source of financing for all types of economic activity in Ukraine, which is not directly related to the development of the financial system.

\footnotetext{
${ }^{12}$ All regression coefficients in the model are statistically significant (p-value does not exceed 0.05 ); adequacy model confirms the absence of autocorrelation residues, homoscedasticity condition is not violated.
} 


\subsection{Summary and conclusions}

After a slight recovery in 2014, there was a rapid decline in the development of Ukraine's financial system during 2015. The level of development of Poland's financial system showed a general upward trend.

General negative changes are also observed in the development of the two main components of the financial system of Ukraine: banking sector and financial markets. The dynamics of both components of Poland's financial system is characteristic of countries that successfully developed.

The declining tendency of the development of the financial system and its components was related to the overall socio-political and economic situation in Ukraine, in particular, the military conflict in the Donbas, which began in 2014, the loss of Russian markets and the devaluation of the national currency.

During the study period, significant changes were also observed in the indicators characterizing the financing patterns of Ukrainian farms. Despite the general negative changes in the integral indicators of the financial system and indicators characterizing the financing patterns of farms in Ukraine, we could not find a strong statistical relationship between them using the correlation analysis process.

In general, there is an average degree of influence of the financial system on the financing patterns of Ukrainian farms, which can be considered quite logical given the significant growth of other current liabilities. This process became possible due to changes in the Tax Code of Ukraine, which allowed the provision of turn-around interest-free financial assistance without the use of traditional financial instruments. As a result, the impact of the financial system's development on changes in financing patterns of Ukrainian farms has become somewhat weaker, compared with the situation observed before 2014 .

Unlike the situation in Ukraine, most of the indicators characterizing the financing patterns of agricultural enterprises in Poland show a significant correlation with the integral indicators of the financial system development and its separate components.

Statistical patterns are found in Poland give some arguments in favour of the confirmation of the hypothesis that the stable development of financial system in advanced economies, generating a gradual increase the role of long-term debt and perpetual own sources of financing of agricultural enterprises, thus create conditions for reducing financial risks of these enterprises.

But the final scientific confirmation of this hypothesis requires further research. 


\section{References}

1. BECK, T., DEMIRGÜÇ-KUNT, A. and MAKSIMOVIC, V. 2008: Financing patterns around the world: are small firms different? Journal of Financial Economics, 89, 467-487.

2. BOOTH, L., AIVAZIAN, V., DEMIRGÜÇ-KUNT, A., MAKSIMOVIC, V. 2001. Capital structure in developing countries. Journal of Finance, 56, 87-130.

3. CENTRAL STATISTICAL OFFICE OF POLAND (CSOP, 2017). Statistical information. https://stat.gov.pl/en/topics/economic-activities-finances/activityof-enterprises-activity-of-companies/.

4. DE JONG, A., KABIR, R., and NGUYEN, T. 2008. Capital structure around the world: The roles of firm- and country-specific determinants, Journal of Banking and Finance, 32, 1954-1969.

5. DEMIRGUC-KUNT, A. and MAKSIMOVIC, V. 1996. Stock Market Development and Firm Financing Choices. Word Bank Economic Review, 10, 341-369.

6. DEMIRGÜÇ-KUNT, A. and MAKSIMOVIC, V. 1999. Institutions, financial markets and firm debt maturity. Journal of Financial Economics, 54, 295-336.

7. FAN, J., TITMAN, S. and TWITE, G. 2010. An international comparison of capital structure and debt maturity choices. Working Paper 16445, http://www.nber.org/papers/w16445

8. GIANNETTI, M. 2003. Do better institutions mitigate agency problems? Evidence from corporate finance choices. Journal of Financial and Quantitative Analysis, 38, 185-212.

9. NATIONAL BANK OF UKRAINE, (NBU, 2017). Statistics // Monetary and financial statistics https://bank.gov.ua/control/uk/publish/article?art_id= $27843415 \&$ cat id $=44578 \# 1$

10.OLIYNYK, O., ADAMENKO, V., \& OLIYNYK, L. 2015. The Comparative Analysis of Financial System of Czech Republic, Poland and Ukraine. Acta Universitatis Agriculturae et Silviculturae Mendelianae Brunensis, 63(6), 2067-2076, https://doi.org/10.11118/actaun201563062067

11.OLIYNYK-DUNN, O. 2017: Financial system and agricultural growth in Ukraine. Organizacija (Journal of Management, Information Systems and Human Resources), 50 (3), 244-253. https://doi.org/10.1515/orga-2017-0016

12. STATE STATISTICS SERVICE OF UKRAINE, (SSSU, 2017). Statistical information. - Retrieved from: http://www.ukrstat.gov.ua

13.THE WORLD BANK, (2017a): World DataBank. Indicators. Retrieved from: http://data.worldbank.org/indicator

14.THE WORLD BANK, (2017b). World Development Indicators. Available: http://databank.worldbank.org/data/views/variableselection/selectvariables.asp $\mathrm{x}$ ?sour

15.THE WORLD BANK, (2017c): World DataBank. Worldwide Governance Indicators, Available: http://databank.worldbank.org/data/reports.aspx? source= worldwide-governance-indicators 